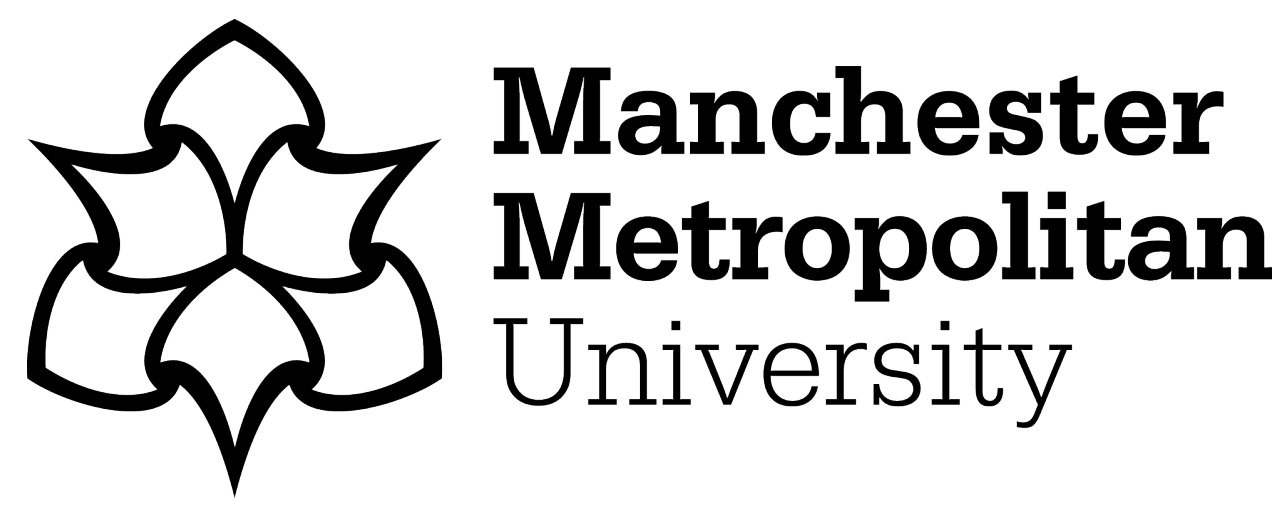

Liggins, E (2019) Visualising the unseen: Supernatural stories and illustration in the strand. Victorian Periodicals Review, 52 (2). pp. 365-387. ISSN 0049-6189

Downloaded from: https://e-space.mmu.ac.uk/625021/

Version: Accepted Version

Publisher: Johns Hopkins University Press

DOI: https://doi.org/10.1353/vpr.2019.0022

Please cite the published version 


\title{
Visualising the Unseen: Supernatural Stories and Illustration in the Strand
}

\author{
EMMA LIGGINS
}

"The Strand has always made a point of taking good stories," claimed a retrospective editorial in I9I I celebrating twenty-one years of a successful magazine. ${ }^{\mathrm{I}}$ As Kate Jackson suggests in her important work on the Strand Magazine's publisher and first editor George Newnes, the ambitious project of "revolutionis[ing] the market for magazines" owed much to Newnes's enthusiastic promotion of the art of short story writing. ${ }^{2}$ By cramming the new magazine with illustrated short fiction, which opened most issues and dominated the contents pages, Newnes catered for a mass audience who could hardly wait for the next instalment of Sherlock Holmes's detective prowess or another thrilling tale of imperial adventure. Quickly becoming renowned for its short stories, the Strand Magazine has now become synonymous with the popularity of fin de siècle detective fiction. Some critical attention has also been paid to its generous inclusion of children's stories by regular contributors such as E. Nesbit, which helped to consolidate its mass appeal. Yet its embracing of other subgenres of the short story has been neglected. Ghost stories and other supernatural tales featuring fantastic creatures such as vampires, fairies, and monsters remained popular from the I 890 o into the twentieth century. The Strand's juxtaposition of these stories with non-fictional articles on spiritualism, science, and technology as well as the illustrations created by the magazine's expert team of artists are worthy of more critical interest.

In this article I argue that paying attention to the illustrations and captions printed alongside ghostly and uncanny stories in the Strand between I 89I and I9I7 can transform our interpretations of how the supernatural was represented during this period. The complex interaction between supernatural story and illustration in the fin de siècle periodical press reveals cultural anxieties and curiosities about new technologies, the afterlife, and the medical profession. Art editors, whose roles were enhanced by 
the end of the century, actively shaped the layout of illustrated magazines that experimented with new forms of visuality. In his excellent reading of Sidney Paget's illustrations for the Holmes stories, Christopher Pittard has claimed that "the role of illustration is crucial to an understanding of how the Strand policed its reading community." " Pittard considers how images of the detective helped frame potentially progressive ideologies within a conservative aesthetic, but how was the reading community positioned in relation to its consumption of illustrations of the ghostly and the uncanny? If, according to Lorraine Janzen Kooistra, "the image/text/reader dialogue will always . . . be a product of its cultural milieu," then fin de siècle readers of illustrated monthlies decoded images of the supernatural in relation to what they knew about science and scepticism. ${ }^{4}$ Drawing on debates about illustration in periodical studies, I consider what is left in or out of the frame in illustrations of the supernatural and what this might tell us about editorial policy on ghosts and the sceptical reader. Pittard argues that Paget's images obscured detail because Newnes “didn't want his readers to be peering too closely at corpses" for fear of compromising the "cheap, healthful literature" he intended to promote, but this claim does not adequately account for ghost stories and their images. ${ }^{5}$ The phantoms, spirits, and terrified witnesses featured in illustrations of ghostly encounters must be interpreted in relation to the climate of uncertainty about spiritualism and the supernatural.

\section{Illustration and the Borders of Acceptability}

The illustrated monthly became one of the bestselling magazine formats of the I 890 os. The successful formula of short fiction, serialised novels or novellas, illustrations, interviews, and glossy photographs catered to new audiences who were receptive to the visual allure of New Journalism. In an early editorial in the Idler Magazine, editor Robert Barr considers the need for an illustrated monthly in an age of mass literacy: "Time had come when a new monthly magazine ought really to be published. Here is a great reading population crying out for printed matter, and yet nobody seems to pay much attention to the appeal." ${ }^{6}$ When Newnes was interviewed for the "Lions in their Dens" series of eminent men in the Idler, his comments on the future of popular journalism revealed his shared awareness of this new audience. Asked about the possibility of providing the masses with the higher journalism, he emphasises the value of the illustrated monthly over the old-style review: "They want things served up with other interesting matter, and with as much of the personal element as it is possible to give them. The masses still incline entirely to the lighter side of literature. They work hard enough in everyday life, their recreation and their literature must, therefore, be as light as possible." ' Defining the "lightness" of 
literature as separate from the everyday has repercussions for the content of the stories and what might lie outside the parameters of an illustrated magazine with a mass audience.

As an illustrated monthly dedicated to popular fiction, the Strand invites discussion of its image/text dynamics. Reminding us of the "lure of illustration," Laurel Brake and Marysa Demoor have highlighted the knowing exploitation of "all possible juxtapositions of text and image" in the nineteenth-century periodical. ${ }^{8}$ The diversity of these juxtapositions demands our attention. Although Newnes's famous maxim of "an illustration on every page" had proved too expensive to maintain, the "pioneering" Strand set a trend for British monthlies with its profuse illustrations adorning each issue. ${ }^{9}$ Reviewing the notable features of the magazine in I9II, the retrospective editorial ranked illustration above fiction, interviews, articles, and photographs: "In the matter of illustrations, for instance, we seemed to be embarking upon the wildest extravagance in furnishing not fewer than a hundred and ten in a single number." ${ }^{\text {1о }}$ Colour printing of fashion plates, photographs, decorated letters, and in the r9Ios a new illustrated masthead featuring classical figures all added to the Strand's visual appeal. The synergy between author and artist, between the literary and the artistic, became the hallmark of the successful illustrated monthly and a key part of its global appeal.

Art was becoming increasingly important to the periodical, as evidenced by the inclusion of art editors in editorial teams and the rise of the celebrity artist or illustrator. Capitalising on the value of art within the periodical market, Newnes took his inspiration from illustrated American monthlies such as Harper's (I 850-present), Scribner's (I 887-I939), and the Atlantic Monthly (I 857 -present), the latter of which carried the tagline "A Magazine of Literature, Art and Politics" as if to grant the three components equal status. In an article in the Strand's hundredth number in April I 899, Newnes linked the popularity of such American magazines to the fact that "they were smarter and livelier, more interesting, bright and cheerful" than British equivalents. ${ }^{\text {II }}$ As Jackson has noted, the Strand was one of the first magazines to include the names of its illustrators on the contents page, testifying to their importance to the development of New Journalism. ${ }^{12}$ The Strand's art editor, W. J. Boot, managed an ever-expanding team of (mainly male) artists whose regular contributions to the magazine made them household names.

Other successful illustrated monthlies with a special emphasis on fiction, such as the Windsor Magazine (I895-1939) and the boys' magazine the Captain (I 899-I924), published stories by some of the same contributors, including Arthur Morrison and E. Nesbit. A Windsor editorial for I 899 suggests that image/text relations guarantee longevity in a periodical: "The only enduring success in magazine reputations is that which depends, 
not upon bounce, brag, or sensational self-advertisement, but upon the publication of THE BEST WORK BY THE BEST AUTHORS AND ARTISTS." " 3 As art editor of the Yellow Book (I 894-97), Aubrey Beardsley gave the magazine a distinctive, decadent look with its decorative spine and androgynous black-and-white figures on the cover. However, its trademark short stories appeared separately from specially commissioned images; the first edition of I 894 included only fifteen art images in its 272 pages, all printed exclusively on the recto facing a blank page, "thereby demanding that they be viewed independently" as in an art gallery. ${ }^{\mathrm{I}}$ In contrast, the illustrations for the Strand stories had to be viewed whilst reading the text, so the art editor's placement and sequence of the images became crucial to interpreting the story.

The coupling of text and image is now recognised as a crucial aspect of periodical studies, with renewed attention being paid to all paratextual material including illustrations, advertisements, and photographs. Gérard Genette has considered the "paratextual value" of prefaces, title pages, dedications, and images that serve to frame and enhance the verbal text. He argues, "Whatever aesthetic or ideological investment the author makes in a paratextual element ... the paratextual element is always subordinate to 'its' text, and this functionality determines the essence of its appeal." ${ }^{\text {I5 }}$ Whilst it is now more commonplace to argue that illustration occupies a central rather than a threshold position within a periodical, its relationship to the "main text" is still open to debate. The placement of illustrations within a short story, both on the page and in relation to the caption, demands further scrutiny. As a feature of the New Journalism, captions became essential to the presentation of images in the illustrated monthly. The majority of illustrations in the Strand include captions in the form of short quotations from the accompanying story or serial, highlighting key scenes from the text; notable exceptions include some of the illustrations embedded around the titles of stories. Illustrations often took precedence over the verbal text, sometimes occupying an entire page and, more often in the twentieth century, a double page. In the era of New Journalism, which relied so heavily on the visual, the paratextual value of illustration was stretched and tested.

The borders of acceptability for the fin de siècle short story conditioned the selection of supernatural narratives and images in mainstream periodicals. In an I 893 Idler article, "Stories and Story-telling," Andrew Lang reflects on the author's dilemma in rising above the familiar and "the hackneyed old story." " Imagining the "ghastly" supernatural tale that French writer Guy de Maupassant could have made out of an undisclosed anecdote, Lang laments that "by our curious British conventions, this tale cannot be told in an English book or magazine." ${ }^{17}$ With its suggestions of immorality, he concedes, it would be better for the French market; another 
anecdote containing "a wonderful scene with a corpse and a chapelle ardente, and a young lady" is also judged unprintable. ${ }^{{ }^{8}}$ The parameters of British periodical fiction may appear to exclude the ghastly as well as the erotic juxtaposition of ladies and corpses, but another look at Strand illustrations suggests that artists sometimes strained against cultural limits and expectations. Margaret D. Stetz has highlighted the shared Gothic elements of illustrations of the racial other in H. G. Wells's imperialist fictions in the Strand and of black Africans in "documentary" accounts of globetrotting in Newnes's magazine the Wide Wide World in I 898. She attributes this similarity to the artists shared by the two periodicals. ${ }^{19}$

Whilst this reiteration of dominant theories of racial degeneration might have confirmed readers' prejudices, other visual images were more unsettling. For example, one of the Strand's recurring images depicted a male doctor examining a patient. Like the detective, the doctor seemed to be a reassuring figure who could unlock some of the mysteries of an uncertain and troubled age. But "medicine's fascination with disease, pathology and death," argues Andrew Smith, "suggested to the press that medicine was inherently perverse and dangerous." ${ }^{\circ \circ}$ Medical fiction, a staple feature of the Strand, can also be usefully read alongside debates about the supernatural and the limits of scientific enquiry. One popular I89os series was "Stories from the Diary of a Doctor" by L. T. Meade and Clifford Halifax, $\mathrm{MD}$, printed under the tagline: "These stories are written in collaboration, with a medical man of large experience. Many are founded on fact, and all are within the region of practical medical science. These stories which may convey an idea of the impossible are only a forecast of an early realization." ${ }^{21}$ The popularity of stories conveying the impossible, a description which could easily apply to supernatural fiction, demonstrates the magazine's enduring fascination with the unknown. James Mussell has importantly identified the Strand's tendency to explain strangeness in its scientific articles and its revelations of "the strange worlds of the invisible" in reproduced photographs. ${ }^{22}$ Strangeness could also be inscribed in the magazine's representations of scientific knowledge as both admirable and alarming.

The Strand's illustrations for medical stories sometimes revealed the uncertain limits and dangers of medical science, unsettling the magazine's expected endorsement of the medical profession. A good example of this is Mary Elizabeth Braddon's chilling vampire story "Good Lady Ducayne" (I 896), in which the sleeping Bella Royston's fresh blood is medically drained by the Italian physician of her aging, witch-like employer, Lady Ducayne. The two doctor figures occupy different ends of the medical spectrum: the Edinburgh-trained Dr. Stafford, who rescues Bella from her plight, knows "all the new-fangled theories, the modern discoveries-that remind one of the medieval witchcraft," whereas Dr. Parravicini, "that wretched Italian quack," conducts "experiments in chemistry and natu- 
ral science-perhaps in alchemy." ${ }^{23}$ Lady Ducayne gestures to the press's general admiration for medical progress when she remarks, "Medicine is a progressive science, the newspapers tell me," and the accompanying illustration by Gordon Browne shows the old lady seated between the two doctors, pointing a gnarled finger at Dr. Parravicini, while the caption states, "His brain power is going." ${ }^{24}$ In contrast, Dr. Stafford, looking rather like a dapper Dr. Watson, signifies the young professional who triumphs over the vampire and her evil assistant. Parravicini's "experimental surgery"the blood transfusions under chloroform that have created the tell-tale lancet marks on Bella's arms-is more scientific than supernatural, but the familiar image of the doctor bending over the younger woman's body in the next illustration bears the ominous caption "What a vampire!" (figure I). ${ }^{25}$

One way of potentially downplaying the supernatural aspects of the medical story was to position it in relation to more factually based articles in the magazine. The opening illustration appears opposite the final photograph from "The Romance of the Museums," a series on cultural artefacts. Thus, an image of Lady Ducayne with a vampire bat's wings outstretched behind her is juxtaposed with some "long-lost chessmen" from "remote antiquity." ${ }^{26}$ Vampiric power is visualised as both ancient and terrifyingly modern in these three illustrations, which capture the strangeness of medical experimentation (only partly defused by the story's happy ending). It is worth noting, however, the limits to what the editorial team would allow. Perhaps so many of Doyle's medical stories were placed outside the Strand because they were considered too shocking for family reading; the darker side of medical science was permitted in more avant-garde publications such as the Idler. Doyle's horrific "The Case of Lady Sannox" (I893), in which Lord Sannox tricks an eminent surgeon into mutilating his wife's supposedly injured lip as a punishment for her adultery, was perhaps a step too far for the Strand. The Idler illustrations by the Misses Hammond show the screaming woman with her hands to her face occupying less visual space than the full-page opening image of the cruel husband with his malevolent smile. ${ }^{27}$ Whilst mutilation lay outside the parameters of the Strand's brand of popular entertainment, the doctor's quasi-vampiric scientific authority aligned medical stories with ghost stories in questioning the realms of possibility.

The mass reading public's standards of acceptability are key to understanding the reception of ghost stories by Strand readers, whose entertainment stopped short of the horrific and unduly disturbing. Kooistra has discussed the "quotational strategy" of illustration in the periodical press, whereby the image authenticates the verbal text and confirms the ideological leanings of the readership; she argues that certain visual signs (of abject poverty or the physical superiority of the Zulu, for exam- 


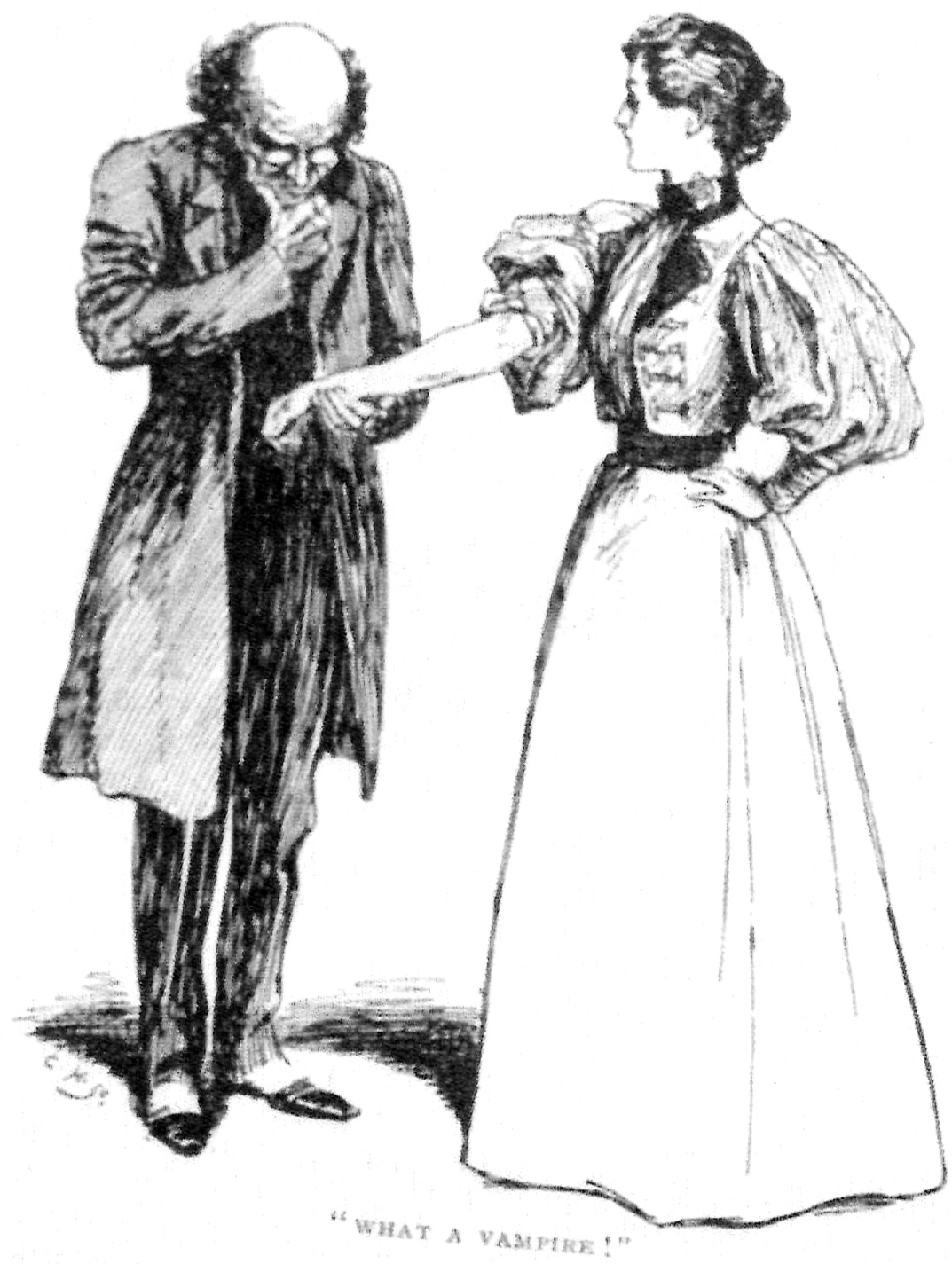

Figure I. Gordon Browne, "What a vampire!" Illustration for "Good Lady Ducayne" by Mary Elizabeth Braddon. Strand Magazine I I (February I 896): I94. Courtesy of Manchester Libraries, Information and Archives. 
ple) would have been too threatening to "middle-class complacency" to be included. ${ }^{28}$ Pictorial journalism was often institutionally censored to appear more comforting than confrontational. Thus, the illustrations for the Holmes stories reiterate crime fiction's reassuring messages of scientific investigation, revealing the criminal and resolving the case. As Pittard has demonstrated, detective stories "reinforce the suppression of sensationalism" by illustrating the cogitating detective in the metropolitan centre of Baker Street more often than the apprehension of criminals or gory crime scenes. ${ }^{29}$ But supernatural fiction follows a different trajectory from crime fiction and, as a genre, shies away from comforting resolutions. By the I 890 s, when psychological understandings of haunting and hallucination predominated, the unexplained supernatural became a much more popular mode, which also played to the mass readership's uncertainty about the existence of ghosts and the spirit realm. Illustrations of apparitions sometimes tricked the reader into believing in "fake" ghosts, but if the supernatural was unexplained, was visual verification possible? In the following sections I consider the visual signs of the supernatural that accompanied short stories in the Strand in the I 890 os and early twentieth century, showing how illustrators imagined the unseen and the unknown as increasingly "strange" at a time when science relied on the visible world.

\section{Ghosts and the Sceptical Reader in the 1890s}

The establishment of the Society for Psychical Research in 1882 and the dissemination of its research on apparitions, haunted houses, and the paranormal in specialist periodicals such as W. T. Stead's Borderlands (I89397) brought the border between life and death into the public eye and encouraged debate on hallucinations and spectral illusions. The Strand was not unusual in positioning images of apparitions alongside articles on scientific inventions, photography, and new communication technologies. Shane McCorristine argues that by rejecting popular phrases such as "ghosts" and "supernatural," the Society for Psychical Research attempted to reclassify apparitions, "thus dragging them away from popular spiritualist beliefs and into the realms of scientific possibility." ${ }^{\circ}$ Literary members of the society, including Doyle, Henry James, Andrew Lang, and others, undoubtedly drew on debates about hallucination or phantasms gleaned from its publications for their own fiction and journalism.

Attempting to place Doyle in relation to the "sceptical reader," Kevin Mills has noted the mismatch between his ghost fictions and "his evangelical quest to promote the Spiritualist cause." ${ }^{\mathrm{I}}$ Doyle's non-fictional writings, he suggests, "seek out and celebrate the (re)appearance of the departed, while his fictions traffick in the terror and horror of Gothic fantasy, in the all-too-unwelcome insurgence of the uncanny." ${ }^{2}$ Mills's arguments about 
a sceptical, scientifically savvy readership are persuasive. Certainly, the Strand encouraged the notion of apparitions as scientifically possible. In "Science in the New Century" (I90I), an eminent engineer looks forward to a future in which scientific achievement will "eclipse its record of the nineteenth century," claiming, "In science ... it is the unexpected which always happens." ${ }_{33}$ J. L. Cranfield has designated this article "totemic" in its "opening out of scientific perspective . . . a coming to terms with the onset of late modernity"; certainly, its emphasis on the validity of the unexpected has wider implications. ${ }^{34}$ This meant that ghost stories could open with a knowing wink to the sceptical reader before exploring the limits of scientific enquiry or speculating about the psychological states that might produce traumatic scenes of haunting. They catered to a forward-thinking audience with mixed feelings on spiritualism and the uncanny.

An early Strand article on "Ghosts" (I89I), written and illustrated by Irving Montagu, captured readers' half-sceptical fascination with the otherworldly, setting the tone for future editions. Flourishing from the I 860 s onwards, the popular phenomenon of spiritualism, or the communication with the dead via mediums and séances, prompted the public to reconsider its beliefs about what lay beyond the grave. If spiritualism can be defined as "a movement concerned with producing physical evidence of life after death," Strand readers were perplexed by the difficulties of decoding this evidence or recognising the limits of scientific enquiry. ${ }^{35}$ Montagu himself adopts this half-sceptical stance on the wide "field of speculation" about ghosts: "Not so unjust to others as to disbelieve all that I cannot understand, I am still far from accepting the manifestations they professedly realise." ${ }^{36}$ Ridiculing the inauthenticity of spiritualist gatherings, the article then goes on to offer a series of ghost stories and legends, some of which involve Montagu's own experiences of haunting while others draw on familiar motifs such as the apparitions of miserly ancestors, skeleton horsemen, phantom bridegrooms, and white ladies. Lurid and fairy-talelike illustrations dominate the pages, particularly the long-haired man draped in white clutching a dagger and surrounded by demons underneath the title (figure 2). In another image, a woman who was executed for murder returns from the grave to claim her sailor lover in a storm at sea under the caption "In the midst a beautiful woman." ${ }_{37}$ The article concludes with an apology for this "glance ... at Ghostland" and hopes that it will afford interest and "pleasure" to readers of the magazine, suggesting that the entertainment value of the supernatural story stems from its incompleteness and even its refusal to explain. Perhaps the ghost becomes one of the "fairy tales of science" that the new century will attempt to convert from the "marvellous" to the "substance of fact." ${ }_{38}$

The possibilities of visualising the ghostly, or what was typically unseen, were mobilised by an ongoing interest in spiritualism and spirit photogra- 


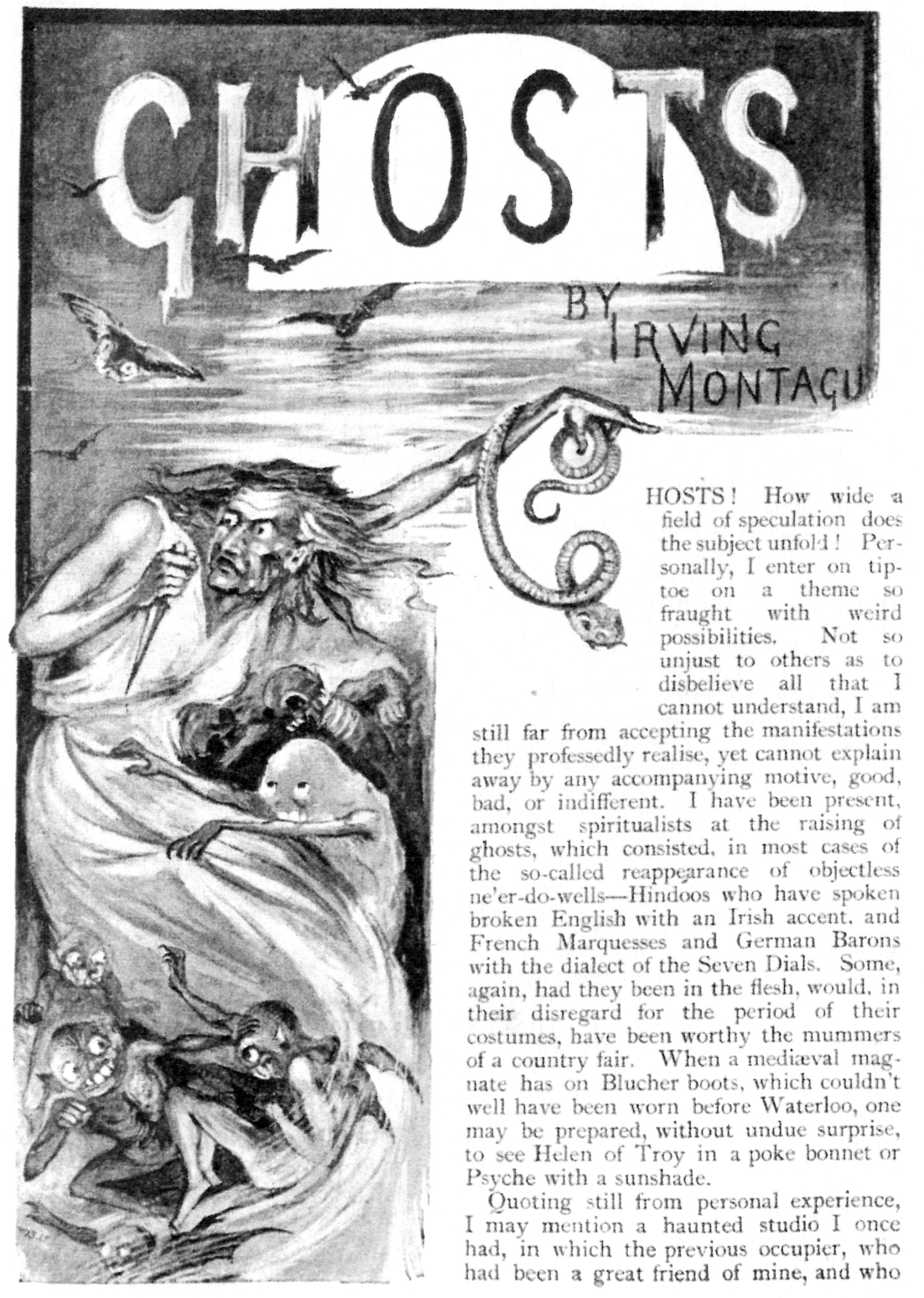

Figure 2. Irving Montagu, “Ghosts.” Strand Magazine 2 (December I89I): 57I. Courtesy of Manchester Libraries, Information and Archives. 
phy. For the sceptical late Victorian, spirit photography might have seemed unviable, but the circulation of such images and the discussions they generated suggests a willingness to believe that ghosts could be captured by modern technology. Doyle would go on to provide "corroborative evidence" of such images in The Case for Spirit Photography (1922); its 1923 dustjacket carried the tagline, "Can the Camera Show Us Those who have Passed Beyond?" ${ }_{39}$ Jen Cadwallader argues, "The popularity of the spirit photograph in the second half of the nineteenth century points to a culture which saw its materialism spilling over into religious doctrine, and whose interest in technology was transforming into a type of religious faith." ${ }_{4}$

Moreover, spirit photographs were not only treasured as artefacts in elaborate mourning rituals but were also objects of scientific enquiry. An example appears in William Fitzgerald's Strand series "Some Curiosities of Modern Photography" in I 895, alongside a description of the experiments of Dr. Traill Taylor and the well-known medium, Mr. David Saguid, "a truly reassuring name" (figure 3 )..$^{4}$ Invoking the sceptical reader, the accompanying text casts doubt on the spiritualist endeavour whilst signalling a reluctant fascination: "And yet ghosts appeared, spirits of departed friends, all nicely draped." ${ }^{2}$ An I 894 Idler article "Photography as Evidence" ostensibly praises the "accuracy" of images used in the pursuit of science, but it also reveals the trickery of the photograph: "Photographs can lie ... their testimony can be secured for things which everyone must at once perceive to be quite impossible." ${ }_{43}$ Such impossibilities included a young man in the midst of breaking open his master's till being confronted with the ghost of his mother; this image is captioned "He saw a ghost." 44 The transparency of the ghost is twice mentioned and appears to be verified by the hazy image of the pointing woman in the picture, though this is not a formal family photograph like the ones used in Cadwallader's research. The purportedly scientific status of the spirit photograph, both a curiosity and an impossibility, remained irreconcilable with the Strand reader's scepticism.

Ghost stories of this period could refer either to supposedly true accounts or to fictional narratives, both of which were printed in the periodical press and were sometimes indistinguishable. In his analysis of testimonies of the spectral, McCorristine has argued that at the fin de siècle "ghost-seeing 'fact' and ghost-seeing 'fiction' need not exist in conflict with each other but are rather dynamically inter-related and cross-pollinating." ${ }^{45}$ The pendulum swing between scepticism and spiritualism is evident in two examples from I 895 where the unseen is conjured up within the illustration yet also remains outside of the frame. "A True Ghost Story" by the Countess of Munster opens by acknowledging that the supernatural tale is generally accepted, unless it is told by a woman: "Not many years ago, people used to sneer at ghosts and ghost stories much more than they do now. . . . 


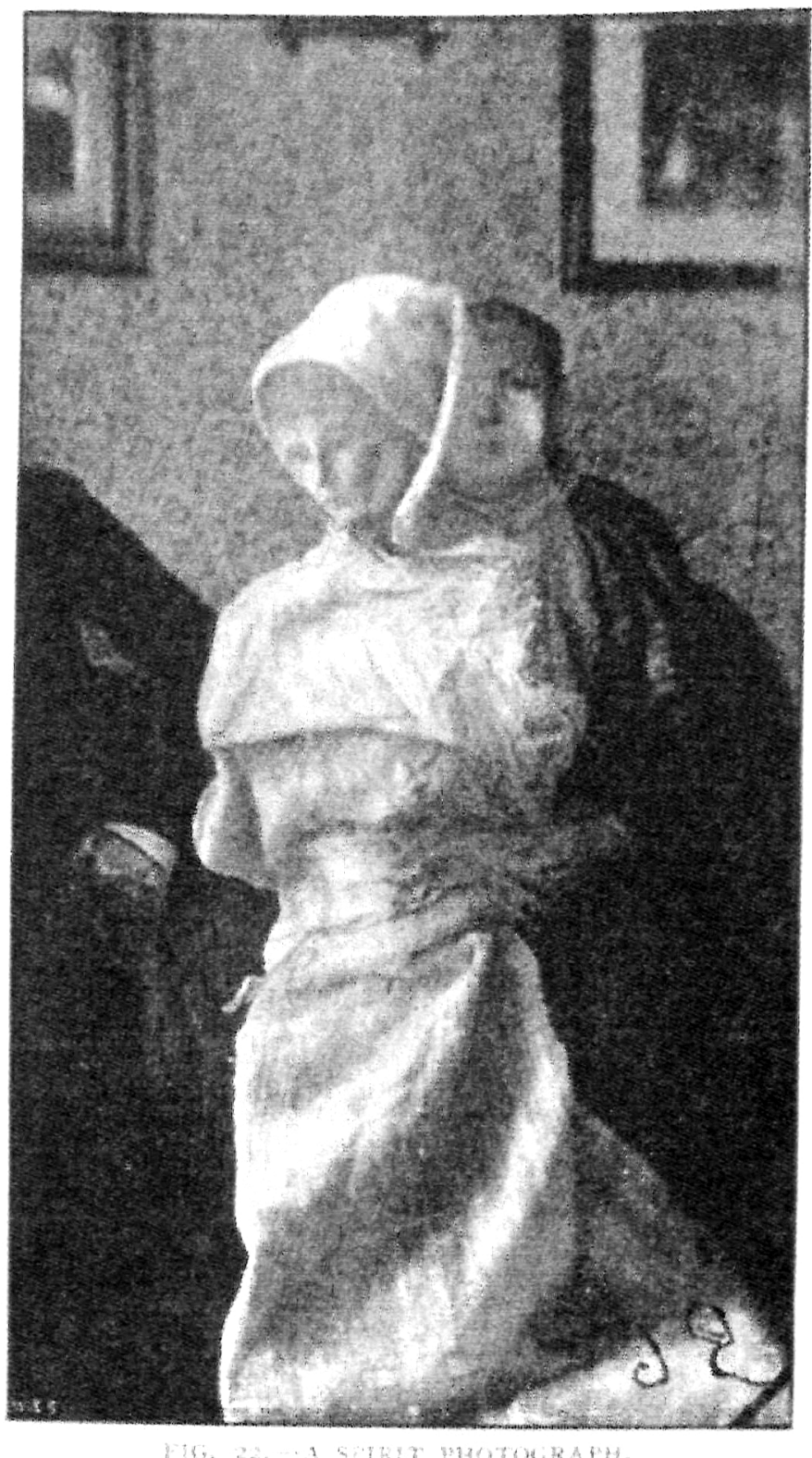

Figure 3. Image from "Some Curiosities of Modern Photography: II" by William G. Fitzgerald. Strand Magazine 9 (February I 895): 201. Courtesy of Manchester Libraries, Information and Archives. 
Yes! People are more accustomed to hearing about ghosts now; and yet, even now, should it be a wife, daughter, or sister who ventures to narrate some supernatural experience, she is pooh-poohed, or laughed at, or told to 'take a pill.' Now, I have seen a ghost-and am prepared to attest most solemnly to the fact." 46 The "fact" of the Countess's haunting is anchored in the "overwhelming affection" and "infatuated adoration" of her single female friend, whom she nurses in her final illness. ${ }^{47}$

The supernatural visit paid by her dead friend appears in the last of three illustrations, produced by the female illustrator Florence N. Upton. The other illustrations draw on familiar Gothic conventions of sickness and the gloomy churchyard: the first shows the narrator pouring medicine into a glass next to her friend's sick-bed, while the second shows the narrator pausing outside a church door above the caption "As I passed the church the clock struck twelve." ${ }^{8}$ Significantly, the final illustration shows a ghostly white vision of the dead friend; the caption "She glided towards me" reiterates the unearthliness of the phantom. The text records the narrator's forgetting that her friend has died: "I really believed I was seeing her in the flesh!" ${ }_{49}$ Given that the dead friend resembles the transparent images familiar from spirit photographs, this seems unlikely. Dreading that she will be disbelieved, the narrator questions the doctor "whether I had betrayed any hysterical tendencies." ${ }^{\circ}$ Mills has identified the narrative convention of "calling the doctor to attend cases of haunting," linking medical authority to the figure of the sceptical reader. ${ }^{51}$ Revealing a similar case, the doctor "not only did not look upon me as a lunatic, but simply as a woman for whom one corner of the curtain which guarded the unseen had been lifted." ${ }_{52}$

Uncertainty about ghosts and spirits is also evident in "An Experience," a French short story in the same volume. The story opens with a fullpage illustration of an imposing Spaniard calling up the dead, bearing the caption "He called some strange, weird-sounding name three times." ${ }_{53} \mathrm{~A}$ group of sceptics staying in a French inn on a stormy night accept the bet of the Spaniard, "a regular gypsy-looking fellow," that he can display his spiritualist powers, and they witness a young man's collapse after supposedly seeing a horrific vision of his drowned friend, though this vision does not appear in text or image. ${ }^{54}$ The narrator asserts, "There are no such things as spirits. I don't believe in them, and never shall." ${ }_{55}$ His suspicion of trickery, despite his niece's arguing the contrary, chimes with his suspicion of the foreigner's strangeness. The final lines of the Countess's story, in which she offers, "should it be required, to give names-in privateto satisfy those who doubt," is perhaps in keeping with editorial policy: readership figures are maximised by juxtaposing impossible images of the unseen with the admission that doubt cannot be resolved within the pages of the magazine. ${ }^{56}$ 


\section{The Uncanny in the Strand Post-1900}

The Strand continued to carry supernatural stories after I900, but changing attitudes to science, spiritualism, and technology reflected in the accompanying non-fictional articles gave them a slightly different context. Cranfield has argued that increasingly forward-looking articles on science after 1900 meant that Strand readers became attuned to "the various ways in which science had penetrated unseen into the daily transactions of their lives." ${ }_{57}$ The strangeness of science can be examined in relation to Sigmund Freud's theory of the uncanny as "overstepping" the "sober truth." ${ }^{8}$ The boundaries between the possible and the impossible, the known and the unknown, were important to both science and the supernatural, as evidenced in the rise of science fiction in the early twentieth century. I have written elsewhere about E. Nesbit's mock-Gothic tales for the Strand, which ultimately preserve the sober truth. For example, "The Haunted House" (I9I3) features an illustration of a ghostly figure captioned "From the coffin rose a form, horribly shrouded," but the illustration's Gothic promise is denied by the textual revelation that the ghost is only a disguised servant acting under the orders of an evil scientist. ${ }^{9}$ However, as the following examples demonstrate, the magazine highlighted the inexplicability of the supernatural and leaned towards strangeness rather than scepticism after 1900 .

H. G. Wells's knowing satire of club culture, "The Story of the Inexperienced Ghost” (I902), illustrated by W. S. Stacey, describes Clayton's encounter with a Cockney ghost after sleeping in the Mermaid Club overnight. Despite the humour around the ghost's awkward attempts at haunting (he "emitted a laughable 'Boo"”), his inability to give a sensible account of "The Other Side of Things," and Clayton's questioning of his business in "a respectable private club," the story nevertheless offers a meditation on the scientific possibilities of "the other side." ${ }^{60}$ Significantly, the story is told to a snorting "party of . . . sceptics" whose doubts are challenged after their friend's sudden and inexplicable death. ${ }^{61}$ Appearing just after the serialisation of Wells's The First Men in the Moon in the Strand in I900-I90I, "The Story of the Inexperienced Ghost" similarly investigates crossing boundaries into the unknown. The first four of its six illustrations strikingly juxtapose the dead and the living, and the image of the blustering gentleman confronted with a semi-transparent ghost in his "vague, intermediate state" is again reminiscent of the spirit photograph (figure 4 ). ${ }^{62}$ The fourth illustration captures the ghost in the process of disappearing, and its caption, "I got the queerness of it full," is echoed in the narrator's feeling "queer" on the next page. ${ }^{63}$ The queerness of imagining the crossing of the barrier between life and death-indeed, Clayton dies while trying to convey the ghost's disappearance-challenges the scepticism of both his 


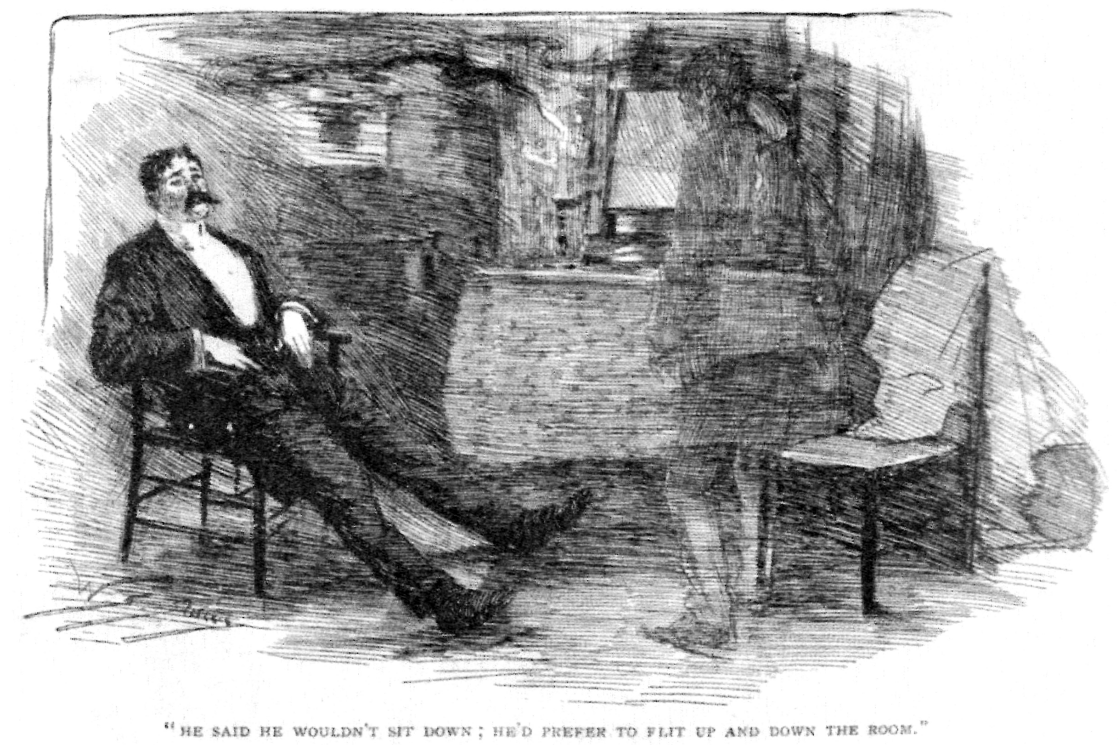

Figure 4. W. S. Stacey, "He said he wouldn't sit down; he'd prefer to flit up and down the room." Illustration for "The Story of the Inexperienced Ghost" by H. G. Wells. Strand Magazine 23 (March I902): 340. Courtesy of Manchester Libraries, Information and Archives.

friends in the story and the Strand's readership. The final two illustrations depict the perplexity and fear of the listeners in the face of sudden death. If, following Genette, the paratextual elements enable the text to be "offered ... to its readers, and more generally, to the public," then these illustrations further challenge the limits of science explored in the verbal text. ${ }^{64}$

The strangeness and limitations of new technologies are also apparent in a number of stories that render machinery supernatural. If readers of the Strand in the new century were "addressed directly as transitional subjects," as Cranfield claims, this sometimes involved a reflection on what transitioning to an uncertain future might entail. ${ }^{65}$ In "Lord Beden's Motor" (I90I), the doctor narrator, Scott, is coerced into a furiously fast ride in Lord Beden's new modern vehicle, "that grey mass of snorting machinery," in order to witness the appearance of a phantom car. ${ }^{66}$ Driven by the apparition of Lord Beden's younger self, the phantom car has smoke and no lights, iron and a huge lever, "bearing no more resemblance to a modern machine than a bone-shaker of 20 years ago does to the modern 'free-wheel." ${ }^{67}$ It had been designed by the earl's late brother, a "mechanical genius" whose plans for his new invention had been stolen when he died in an asylum. It is significant that both men see the phantom car, which the earl fears is "a fancy of my brain." ${ }_{68}^{8}$ The earl's attempt to 
grasp the phantasm of his former self is like "clutching the air . . neither car nor occupant appeared to have any tangible substance." ${ }^{69}$ The doctor's fears that his patient is "over-doing" the motor business and that they will be "dashed to pieces" results in his desire to "overpower Lord Beden and gain control of the machine," as if to defy the supernatural with his medical prowess. ${ }^{70}$

Although the earl's death in the final crash can be read as a cautionary note on the dangers of speed ("motor-car accidents are common enough," the narrator asserts), the visual text reinforces the uncanniness of the two models of car almost superimposed. ${ }^{7 \mathrm{~T}}$ The final illustration is captioned "Steadily and silently we bored our way clean through the machine." 72 Such an image of impossibility may have served a purpose similar to spirit photographs, which "helped Victorians negotiate the place of spirituality in an increasingly modernized, technologically advanced society." 73 Indeed, this volume of the Strand offered many images of impossibility, including an article on "Natural Optical Illusions" and illustrations of Selenites, the tentacled aliens described in Wells's The First Men in the Moon as both a "mad impossibility" and "strange creatures" whose uncanny appearance terrifies and intrigues the scientists. ${ }^{74}$ Whilst the doctor's "miraculous escape" at the end of "Lord Beden's Motor" seals his silence on the supernatural encounter, his earlier comment on the phantom car, "I can see it," paradoxically suggests a scientific verification of the intangible. The quotational strategy of the images of the phantom car works here to unsettle readers' perceptions of the ghostly, as despite aligning themselves with the sceptical doctor, they can hardly believe their eyes.

Writing on the challenges of interpreting visual material, Kooistra has asked, "How did [the] structures of the printed page shape the reader's experience?" 75 Page layout, including the sequence and size of illustrations in relation to the story, influences how readers might have interpreted the tone and themes. In the double-page final illustration for E. Nesbit's chilling story "The Pavilion" (I9I 5), the distraught heroine gathers in her arms the dead guest strangled by a man-eating creeper after foolishly accepting a bet to sleep in a notoriously haunted space. The scene is described on the previous page: "On the bench lay the dead man and kneeling by him a living woman on whose warm breast his cold and heavy head lay pillowed. The dead man's hands were full of the green crushed leaves, and thick twining tendrils were about his wrists and throat." ${ }^{76}$ Tendrils from the supernatural plant protrude from a window behind the couple above the caption "The woman never spoke. She sat there in the white ring of her crinolined dress like a broken white rose. But her arms were around Thesinger and she would not move them." 77

The double-page spread demands a lengthy caption, which oddly does not capture the horror of the supernatural encounter but instead diverts 
attention towards the "broken" heroine, who has been denied a potential marriage partner. The crinoline, a restrictive fashion of the mid-Victorian era when the story is set, also features in two of James Durden's illustrations for the beginning of the story, as if to emphasise the nostalgic security of the story before its ghastly denouement. Visually, the couple in Nesbit's story is set apart from their party of friends by the dividing line between recto and verso; they appear under the recto running head, "The Pavilion" (the haunted space), whereas the horrified but intrigued male onlookers remain under the header, "The Strand Magazine," as if aligning themselves with the (half) sceptical Strand reader. According to Minna Vuohelainen, the settings of short ghost fiction of the fin de siècle featured not only cemeteries but colonies, gardens, cinemas, prisons, museums, suburbs, ships, trains, and hotels, all heterotopias "seemingly removed from ordinary life." ${ }^{78}$ Whilst the haunted pavilion with its exotic plants offers another example of a liminal space, what makes this story chilling is the uncanny encounter's proximity to ordinary life, the ease with which scepticism and banter about ghost stories can turn to the sinister and strange.

The war years saw a revival of interest in spiritualism, popularised in texts such as Sir Oliver Lodge's Raymond or Life and Death (I9I6) about the Society for Psychical Research's former president's communication with the spirit of his son who was killed in conflict. A debate between Arthur Conan Doyle and the anthropologist and sceptic Edward Clodd, "Is Sir Oliver Lodge Right? Can the Dead Communicate with the Living?" was deemed important enough to be advertised on the Strand's July I9I7 cover. Doyle follows the society's mindset in "dignifying [spiritualism] into a scientific philosophy," whilst Clodd describes believers as duped by "delusions ... [ [with] unstable foundations," bent only on satisfying "the insatiate appetite for the marvellous." 79 In the same volume, L. G. Moberly's "Inexplicable," a sinister story about a haunted suburban house infested by supernatural alligators, used the uncanny to recall the inexplicable trauma of participation. Materialising from an ornate occasional table carved with lifelike images of their scaly bodies, the half-invisible alligators symbolise the dangers of imperial endeavour as well as the irruption of repressed memories of service abroad. Slithering around the servants' bedrooms at night and tripping up Hugh (the narrator's husband) and his guest by twining around their legs, the supernatural creatures bring the horrors of war into the heart of suburbia. The narrator's attempts to put her new house into "liveable order" and placate her terrified domestic staff are thwarted by the malevolent table, with its horrible sound of bellowing and the odious smell it emanates through the house.$^{80}$ For their visitor Jack Wilding, the damp smell recalls a fatal alligator encounter during his service in New Guinea. Dudley Tennant's almost full-page illustration depicts the traumatic memory of Jack's survival and his friend's last moments with 
the caption "I crossed an alligator swamp once with a friend, and they dragged him off the path of logs in the darkness." ${ }^{8}$

As if to validate the Strand's strangeness, Moberly's story appears as an often forgotten reference in Freud's "The 'Uncanny": he called it "a naïve enough story, but the uncanny feeling it produced was quite remarkable." ${ }^{2}$ In theorising "the problem of the uncanny," Freud particularly noted the differences between experiencing the uncanny and picturing or reading about it. ${ }^{8}$ Picturing the uncanny becomes a way of mediating fictional and non-fictional experiences of the unknowable. Thus, the final double-page illustration in "The Inexplicable" sensationalises the supernatural encounter by showing the terrified husband and wife in their home's entrance hall on the left with a sinister crocodile halfway down the stairs on the right. As in the Nesbit example, the verso header, "The Strand Magazine," hovers over the couple and aligns them with the terrified readers, whilst the uncanny figure appears under the title header, "Inexplicable." ${ }_{44}$ The concluding text of the story, which appears under the ghostly crocodile, both dismisses and questions the supernatural. The house agent's clerk shrugs off "unpleasant stories about the house" as "a few silly servants' tales," whilst Hugh recounts his burning of the infernal ornament as the only way to exorcise evil, so the house now shows "no sign of abnormality." ${ }_{5}$ The final sentences invite the reader to share in the wife's recognition of the uncanny: "It was many a long day before I could live down those weird experiences, and even now they are to me quite inexplicable. Does any explanation of it all occur to you?" 86 As a woman writer, Moberly may have used the sinister crocodiles to signal the inexplicability of wartime trauma for women on the home front; the legacy of malevolence, left behind by the previous gentleman tenant who had "not cared" to take the table with him, was perhaps something for women readers of the magazine to try to "live down." 87

The Strand's agenda of "afford[ing] innocent entertainment to the public," particularly in the form of "healthy popular literature," needs to be reconsidered in relation to its publication of supernatural stories, which were less entertaining adventures than unsettling glimpses of the unknown. ${ }^{88}$ The stories considered here, by familiar writers such as H. G. Wells and E. Nesbit as well as lesser-known figures such as L. G. Moberly, demonstrate the importance of uncanny stories to the magazine and the diverse ways in which both male and female contributors conceptualised the borders between life and death from the I 890 s to the First World War. In the space of the Strand the ghostly became "a theme so fraught with weird possibilities," to borrow from Irving Montagu's I89I article on "Ghosts," that it generated new imaginings of what lay outside the realm of science and fed into the magazine's wider meditations on the strange and sinister. Kooistra's theory about the quotational strategies of illustra- 
tion thus needs to take more account of the complexities of what Freud referred to as "pictur[ing]" the uncanny. ${ }^{89}$ A closer look at the image/ text dynamics in the Strand suggests that these neglected uncanny stories coerced the reading community, like the illustrators, into visualising the unseen and, ultimately, confronted sceptical readers with images that could not be explained. The illustrations for ghost stories in the Strand did not serve the same reassuring purposes as those for detective fiction but instead highlighted uncertainties and questions about the existence of ghosts and the possibilities of spiritualist communication, reiterating the inexplicability of the supernatural.

Manchester Metropolitan University

\section{NOTES}

I. "The Twenty-First Birthday," 61 5 .

2. Jackson, George Newnes, 93.

3. Pittard, Purity and Contamination, 88, 89.

4. Kooistra, The Artist as Critic, I 5.

5. Pittard, Purity and Contamination, 89 .

6. Barr, "Idler’s Club," Io6.

7. Blathwayt, "George Newnes at Putney," I73; italics in the original.

8. Brake and Demoor, The Lure of Illustration, I2.

9. Newnes, "The One Hundredth Number," 363.

Iо. "The Twenty-First Birthday," 6I 5 .

I I. Newnes, "The One Hundredth Number," 363.

I2. Jackson, George Newnes, IоI.

I3. "Our Plans for I 899," I 30.

I4. Denisoff and Kooistra, "Introduction to Volume I of the Yellow Book," 2.

I 5. Genette, Paratexts, 8, I 2.

I6. Lang, "Stories and Story-telling," 83.

I7. Ibid.

I8. Ibid.

I9. Stetz, “'Can Anyone Picture My Agony?,” 3 I.

20. Smith, Victorian Demons, Iо.

2I. Meade and Halifax, "Stories from the Diary of a Doctor," 80.

22. Mussell, Science, Time and Space, $75,83$.

23. Braddon, "Good Lady Ducayne," 197.

24. Ibid.

25. Ibid., I94.

26. Ibid., I 85 ; Fitzgerald, "The Romance of the Museums," I 84.

27. Doyle, "The Case of Lady Sannox," 332.

28. Kooistra, The Artist as Critic, 56. 
29. Pittard, Purity and Contamination, 96.

30. McCorristine, Spectres of the Self, I 40.

3 I. Mills, "Conan Doyle’s Sceptical Reader," I 26.

32. Ibid.

33. Dolman, "Science in the New Century," 58.

34. Cranfield, "Arthur Conan Doyle," 9.

35. Cadwallader, "Spirit Photography," I2, I4.

36. Montagu, "Ghosts," 57I.

37. Ibid., 575 .

38. Dolman, "Science in the New Century," 57.

39. Doyle, The Case for Spirit Photography.

40. Cadwallader, "Spirit Photography," I 2.

4I. Fitzgerald, "Some Curiosities of Modern Photography," 20 I.

42. Ibid.

43. Jelf, "Photography as Evidence," 524, 5 I 8; italics in the original.

44. Ibid., 524 .

45. McCorristine, Spectres of the Self, 227.

46. Countess of Munster, "A True Ghost Story," 27.

47. Ibid., 28.

48. Ibid., 28, 29.

49. Ibid., 30 ; italics in the original.

50. Ibid.

5I. Mills, “Conan Doyle's Sceptical Reader,” I 28.

52. Countess of Munster, "A True Ghost Story," 30.

53. Soulie, “An Experience," 363.

54. Ibid., 364 .

55. Ibid., 366.

56. Countess of Munster, "A True Ghost Story,” 30.

57. Cranfield, "Arthur Conan Doyle," I6.

58. Freud, “The 'Uncanny," 250.

59. Liggins, "Beyond the Haunted House," 38.

6o. Wells, "The Story of the Inexperienced Ghost," 339.

6I. Ibid., 338 .

62. Ibid., 340 .

63. Ibid., 342, 343 .

64. Genette, Paratexts, I.

65. Cranfield, Twentieth-Century Victorian, 44.

66. Harris-Burland, "Lord Beden's Motor," 656.

67. Ibid., 658 .

68. Ibid., 660 .

69. Ibid., 662.

70. Ibid., 66I.

7I. Ibid. 
72. Ibid., 663 .

73. Cadwallader, "Spirit Photography," 26.

74. Wells, "The First Men in the Moon," 280, $28 \mathrm{I}$.

75. Kooistra, "Charting Rocks in the Golden Stream," $38 \mathrm{I}$.

76. Nesbit, "The Pavilion," 569.

77. Ibid., 567-68.

78. Vuohelainen, Richard Marsh, 89, 88.

79. Doyle and Clodd, "Can the Dead Communicate with the Living?," 5I, 54.

80. Moberly, “The Inexplicable," 573.

8 I. Ibid., 577.

82. Freud, "The 'Uncanny," 245.

83. Ibid., 247.

84. Moberly, "The Inexplicable," 580-8I.

85 . Ibid., $58 \mathrm{I}$.

86. Ibid.

87. Ibid.

88. "The Twenty-First Birthday," 622.

89. Freud, "The 'Uncanny," 247.

\section{BIBLIOGRAPHY}

Barr, Robert. "Idler's Club.” Idler Magazine I (February I 892): Io6-7.

Blathwayt, Raymond. "George Newnes at Putney.” Idler Magazine 4 (March I894): I60-73.

Braddon, Mary Elizabeth. “Good Lady Ducayne.” Strand Magazine I I (February I896): I 85-99.

Brake, Laurel, and Marysa Demoor, eds. The Lure of Illustration in the Nineteenth Century: Picture and Press. Basingstoke: Palgrave, 2009.

Cadwallader, Jen. "Spirit Photography and the Victorian Culture of Mourning." Modern Language Studies 37, no. 2 (2008): 8-3 I.

Countess of Munster. “A True Ghost Story.” Strand Magazine 9 (January I 895): 27-30.

Cranfield, J. L. “Arthur Conan Doyle, H. G. Wells and The Strand Magazine's Long I90I: From Baskerville to the Moon.” English Literature in Transition, I880-I920 56, no. I (2013): 3-32.

- Twentieth-Century Victorian: Arthur Conan Doyle and the Strand Magazine, I891-1930. Edinburgh: Edinburgh University Press, 2016.

Denisoff, Dennis, and Lorraine Janzen Kooistra. "Introduction to Volume I of the Yellow Book." Yellow Nineties Online (20I I): I-5. www.I890s.ca/PDFs/ YVVI_Intro.pdf.

Dolman, Frederick. "Science in the New Century." Strand Magazine 2I (January I90I): $57-65$. 
Doyle, Arthur Conan. The Case for Spirit Photography. New York: George H. Doran, I923. Arthur Conan Doyle Encyclopaedia. https://www.arthur-conandoyle.com/index.php?title=The_Case_for_Spirit_Photography\#Preface.

—. "The Case of Lady Sannox." Idler Magazine 4 (November I 893): 33042.

Doyle, Arthur Conan, and Edward Clodd. "Can the Dead Communicate with the Living?" Strand Magazine 54 (July I9I7): 49-54.

Fitzgerald, William. “The Romance of the Museums: II.” Strand Magazine I I (February I 896): I77-84.

- "Some Curiosities of Modern Photography: II." Strand Magazine 9 (February I 895): I 9I-202.

Freud, Sigmund. "The 'Uncanny." In The Standard Edition of the Complete Psychological Works of Sigmund Freud, vol. I7, I917-I919: An Infantile Neurosis and Other Works, translated by James Strachey, 21 8-52. London: Hogarth Press, I955.

Genette, Gérard. Paratexts: Thresholds of Interpretation. Translated by Jane E. Lewin. Cambridge: Cambridge University Press, I997.

Harris-Burland, J. B. “Lord Beden's Motor.” Strand Magazine 22 (December I90I): 656-6I.

Jackson, Kate. George Newnes and the New Journalism in Britain, I880-1910: Culture and Profit. Aldershot: Ashgate, 200I.

Jelf, E. A. "Photography as Evidence." Idler Magazine 4 (January I 894): 517-25. Kooistra, Lorraine Janzen. The Artist as Critic: Bitextuality in Fin-de-Siècle Illustrated Books. Aldershot: Scolar Press, I995.

—. "Charting Rocks in the Golden Stream, or Why Textual Ornaments Matter to Victorian Periodicals Studies." Victorian Periodicals Review 49, no. 3 (2016): 375-95.

Lang, Andrew. “Stories and Story-telling.” Idler Magazine 4 (August I 893): $8 \mathrm{I}-87$.

Liggins, Emma. “Beyond the Haunted House: Modernist Women’s Ghost Stories and the Troubling of Modernity." In British Women Short Story Writers: The New Woman to Now, edited by Emma Young and James Bailey, 32-49. Edinburgh: Edinburgh University Press, 2015.

McCorristine, Shane. Spectres of the Self: Thinking about Ghosts and GhostSeeing in England, I750-I920. Cambridge: Cambridge University Press, 2010. Meade, L. T., and Clifford Halifax. "Stories from the Diary of a Doctor." Strand Magazine Io (July I 895): 80-95.

Mills, Kevin. "Conan Doyle's Sceptical Reader: Ghost Stories, Science, and Spiritualism." In The Routledge Handbook to the Ghost Story, edited by Scott Brewster and Luke Thurston, I24-33. London: Routledge, 2018.

Moberly, L. G. “The Inexplicable.” Strand Magazine 54 (December I9I7): 572$8 \mathrm{I}$. 
Montagu, Irving. “Ghosts.” Strand Magazine 2 (December I89I): 57 I-77.

Mussell, James. Science, Time and Space in the Late Nineteenth-Century Periodical: Movable Types. Aldershot: Ashgate, 2007.

Nesbit, E. "The Pavilion." Strand Magazine 49 (May I9 I 5): 562-72.

Newnes, George. “The One Hundredth Number of 'The Strand Magazine': A Chat about Its History." Strand Magazine I7 (April I 899): 363-64.

“Our Plans for I 899.” Windsor Magazine 9 (December I 898): I30-3 I.

Pittard, Christopher. Purity and Contamination in Late Victorian Detective Fiction. Aldershot: Ashgate, 20 I I.

Smith, Andrew. Victorian Demons: Medicine, Masculinity and the Gothic at the Fin-de-Siecle. Manchester: Manchester University Press, 2004.

Soulie, F. “An Experience.” Translated by Alys Hallard. Strand Magazine ro (September I 895): 363-66.

Stetz, Margaret D. “'Can Anyone Picture My Agony?': Visualizing Gender, Imperialism and Gothic Horror in the Wide World Magazine of i 898." Victorian Periodicals Review 40, no. I (2007): 24-43.

"The Twenty-First Birthday of 'The Strand Magazine." Strand Magazine 42 (December I9II): 6I 5-22.

Vuohelainen, Minna. Richard Marsh. Cardiff: University of Wales Press, 2015.

Wells, H. G. "The First Men in the Moon.” Strand Magazine 2I (March I90I): 279-90.

- "The Story of the Inexperienced Ghost." Strand Magazine 23 (March I902): $337-45$. 